\title{
Ethnicity and State Politics in Africa
}

\section{Georges Nzongola-Ntalaja*}

\begin{abstract}
Since the beginning of the still current conflict in the Democratic Republic of the Congo, there has been a debate on the relationship between ethnicity and the pressures for redrawing boundaries in Africa. Most contributors to this dehate have taken the view that these pressures are driven by deep-seated ethnic conflicts. This perspective is questionable, especially in view of the strong official and popular commitment in Africa to the territorial entities inherited from colonial rule. This essay suggests that secessionist movements and cross-border invasions by neighbours, pursuing their own national interests, have becn a greater threat to Africa's existing political map than cthnicity per se. Where ethnicity has featured in the discourses of politicians and military commanders, it has served as little more than an instrument for rationalising the expansionist aims of a state towards a neighbour.
\end{abstract}

\section{Résumé}

Depuis l'éclatement du conflit qui perdure encore en république démocratique du Congo, l'on assiste à un débat sur les relations entre ethnicité et les pressions pour un nouveau tracé des frontières on Afrique. La plupart des intervenants dans ce débat sont d'avis que ces pressions sont nues par des conflits ethniques profonds. Ce point de vue est très discutable, surtout au regard de l'attachement ferme des gouvernements et des populations aux entités territoriales héritées de la colonisation. Le présent essai sugère que les mouvements irrédentistes de même que les invasions trans-frontalières par des voisins à la poursuite de leurs propres intérêts nationaux, ont constitué une menace plus grande de l'existence de la carte politique de l'Afrique que l'ethnicité figure en bonne place dans les discours des politiques et des chefs militaires, elle n'est rien de plus qu'un instrument de justification des pelleités expansionnistes d'un Etat envers un voisin.

* Cicorges Nzongola-Ntalaja was, until recently, the James K. Batten professor of public policy at Dividson College. He had originally prepared this article for the African Studies Programme at Creorgetown University, Washington, D.C. in April 1999. 


\section{Introduction}

The second invasion of the Democratic Republic of the Congo (DRC) by Rwanda and Uganda in 1998 has again revived the debate on the national question, as it relates to the political map of Africa. With the Congo virtually partitioned in two by armies from at least eight different states, some observers are already predicting that the current war may lead to the redrawing of African boundaries. If this were indeed to take place, it would be a function of the cconomic and political interests of the states involved. Most observers seem to think that the ethnic factor provides the trigger for redrawing boundaries. The current boundaries are said to have 'little to do with geography or the lines that separated ethnic groups'.'

Ethnic identity construction and mobilisation have increased as a result of the economic and political insecurity that many countries have experienced in the wake of severe economic crises and the violent backlash of authoritarian rulers against the democracy movement. In addition to occurring in the forms of inter-communal violence and rebellions by oppressed minoritics, ethnic conflict on a major scale has also taken place as political and social oppression by states and by non-state political organisations in the forms of ethnic cleansing and genocide.

This paper attempts to explain the role of ethnic identity politics in the intrastate and interstate conflicts that have afflicted Africa since independence. My argument is that however deep-seated ethnic conflicts might be, they have made less impact in disturbing the political map of Africa than secessionist movements and crossborder invasions by neighbouring states. In the absence of the latter two variables, ethnicity alone is a most unlikely factor for changing boundaries. The commitment to the territorial entities inherited from the colonial period is extremely strong among Africa's rulers and people. Ethnicity can be used in this context only to rationalise the expansionist aims of a state toward a neighbour, as in the use which Rwanda makes of the Congolese Tutsi. On the other hand, states with major powers as strategic allies have had the political backing and the military capacity to embark on crossborder adventures, with a view to establishing control, de jure or de facto, over either part or the whole of another country. 
This paper is divided into three separate parts. The first part is a general discussion of the economic and political roots of ethnic identity politics in Africa. The second part looks at the major types and manifestations of ethnic identity conflicts, while the third and last part shows that ethnicity is not a major factor in cross-border invasions and annexations of forcign territory.

\section{The Economic and Political Roots of Ethnic Identity Politics in Postcolonial Africa}

As a form of social polarisation and antagonism, ethnic conflicts belong to a category of human conflicts based on racial, regional, ethnic, rcligious or communal ties, which are known as identitybased conflicts. Such conflicts may involve the struggle for physical space as well as for social well-being, and have to do with both biological needs for food, shelter and clothing, and sociopyschological needs for identity, security, recognition, participation and autonomy. Ignoring or suppressing such basic human needs is likely to give rise to violent conflicts.?

A question which readily comes to mind is why violent conflicts should result from antagonism between groups based on differences in identity. What is it about communal, ethnic, racial, regional or religious differences that drives human beings to kill and maim each other? For much of the Western world, the answer to such a question with respect to Africa is not a difficult one. In the Western news media, for example, the popular image of Africa is one of countries rent by ancient tribal enmities, which complicate and retard the development of national consciousness. Nearly all African political crises are explained in terms of 'tribalism', defined as attachment to one's 'tribe' or ethnic group, which constitutes a more relevant unit of identification than the country as a whole.

This image of Africa was given scientific respectability in the early 1960s by anthropologist Clifford Geertz's thesis that 'primordial' sentiments were the most relevant factor of social reality in the ncwly independent countries. ${ }^{3}$ The thesis was enthusiastically adopted by modernisation theorists in political science. David Apter and Aristide Zolberg were among the most influential ana- 
lysts to apply it to Africa. ${ }^{4}$ The major statement on the subject is in Zolberg's 1968 article in the American Political Science Review. His views on the political significance of primordial lines of social cleavage were undoubtedly influenced by the theorics of modernisation developed by Apter, who was his comparative politics teacher at the University of Chicago. More recently, the primordial sentiments thesis has been revived by Groran Hyden, who refers to primordial ties of solidarity as 'the economy of affection'.

According to this school of thought, whose ablest representative in African studies literature is Goran Hyden, Africa will in due course cvolve from tribal to non-tribal society, from mechanical to organic solidarity, from ascriptive-oriented to achievement-oriented behaviour, and from the cconomy of affection to a rational-legal economic order. There are no shortcuts to development. The only development strategy necessary for cffecting a successful transition, and the one that Hyden proposes, is that of strengthening an indigenous capitalist bourgeoisie, which is unfettered by state regulations and left free to wage a deadly battle against precapitalist structures and mentalities. Peasant power, interests and autonomy must be sacrificed for the sake of national development. In short, the new nation is born through the passing away of traditional society. "Virtually all of the major policy options dear to public choice theorists, who now influence the pro-market and anti-social positions of the IMF and the World Bank, were already laid out in Hyden's strictures against the 'economy of affection'.

There is no a priori reason why social ties and sentiments based on blood and kinship should necessarily and at all times take precedence over all other forms of solidarity. Contrary to the modernisation theory's thesis, identity-based conflicts are not necessarily a function of ancient enmities, since identities are historically constructed, and may shift with changing circumstances. Moreover, there is a lot of social science evidence that identity ties and sentiments are situational, which is to say that their intensity varies according to circumstances. In situations of relative security, an individual's or a group's identity is not a matter of particular concern. It is when a threat arises, or is perceived, to a group's identity or 
(because of that identity) to its very existence that loyalty to and solidarity with fellow group members becomes paramount.

In Africa, many of the identities behind current ethnic conflicts arose or acquired their specific importance during the colonial period. ${ }^{7}$ As in Rwanda and Burundi, ethnic identity construction and mobilisation were often tied both to the colonial strategy of divide and rulc and to competition for status, wealth and power among the évolués or educated Africans. In the post-war struggle, first for social advancement, and later on for decolonisation and independence, the ability of the African elite to score points against the colonial masters depended greatly on how well they could mobilise the masses behind their social and political demands. Getting the support of the urban masses for these demands required very little effort, as wage workers and the lumpen proletariat interacted with their more educated kith and kin, through ethnically based mutual aid associations. The more difficult task was to raise ethnic consciousness in the countryside, which often required the despatching of 'ethnic missionaries' to spread the gospel of group solidarity and social upliftment in the rural homeland. ${ }^{8}$

In Rwanda and Burundi, where the rival groups do not have separate homelands, this raising of ethnic consciousness primarily took place as armed propaganda. Individuals were challenged to prove their ethnic worth by killing the enemy. By this token, the conflict went beyond inter-communal violence over economic and social space to ethnic cleansing and ultimately to group extermination. The genocide idcology inherent in this process was the logical conclusion of the survival strategy that was born out of real or perceived threats to group identity and sccurity. 'The logic here was simple: either you eliminate the other or you run the risk of being eliminated by it. The other is demonised as the incarnation of all evil, and is animalised by being portrayed as 'insects', 'cockroaches' or other animal creatures. Once dehumanised in this way, the hated group can be exterminated, without causing any moral problems.

The rising number of identity-based conflicts in Africa today is undoubtedly a function of the economic and political instability resulting from the world-wide economic crisis that began in 1975 and from the political upheavals which hit the continent after the 
current phase of the democracy movement was unleashed in 1988.9 The dramatic rise in oil prices and the drastic fall in the world market prices of some major export commodities in 1974 had a devastating effect on many African countries. Economic conditions deteriorated greatly during the $1.980 \mathrm{~s}$, owing to unfavourable terms of trade, increases in real interest rates on external debt, reduced inflow of resources, and massive capital outflows.

The impact of the crisis on the domestic economy was catastrophic, with implications for the economic and social infrastructure. A major aspect of this impact was a significant decline in domestic investment, which led to a decrease in the productive capacity and the growth potential of African economies and to rising unemployment. A corollary of this decline in investment was a decline in the relative importance of industry in the structure of African economies, resulting in some cases in deindustrialisation, ${ }^{10}$ and everywhere in blocking the structural transformations necessary for job creation. Another major impact of the crisis on the domestic economy was a decline in general government spending, which resulted not only in the neglect of social and economic services (roads, energy resources, hospitals and other health-care facilities, schools and universities, research, agricultural extension and credit programmes), but also in the inability of the state to meet its own wage bill on a regular basis.

The consequences of all this for social well-being are well known. They include a dccline in real incomes for most social groups and a decline in food availability, as food production in most countries lagged behind population growth. The rural areas experienced a decline in real incomes and a scrious deterioration in the availability of public services and consumer goods. In the urban sector, wage and salary workers were hardest hit by retrenchment and a more hostile work environment, in which private employers and the state alike took advantage of massive unemployment to impose low wages and unsatisfactory working conditions.

With the decline in formal sector employment and in real wages, there has been a phenomenal rise in overt unemployment and in the expansion of the informal sector of the economy. Even the salaried middle classes have becn relatively impoverished, with medical doctors and university professors on the state payroll hav- 
ing to engage in some kind of private business in order to make ends meet. Only the rich, whose very wealth is built on either the injustices of the past for white settlers or the privatisation of the state and of the resources it controls by African rulers and their entourage, have been able to withstand the crisis.

The social and political implications of the economic crisis for African countries are well reflected in the rising levels of violence and the increasing number of identity-based conflicts. In South Africa, for example, what appears to be criminal violence seems, at least in one case, to be a manifestation of identity-based conflicts. I refer to the sustained and numerous attacks on white farmers by black militants, determined to drive the settlers off the land. The attempt by peasants to occupy white-owned farms in Zimbabwe seems to follow a similar logic, albeit in a different way. Elsewhere, popular frustration with the unfulfilled expectations of independence, economic stagnation and the slow pace of political change are often translated into identity-based conflicts, rebellions against state authority, or a combination of both.

This is made possible by a combination of at least three contributing factors:

(1) the large number of unemployed young people and school leavers with nothing to do and no hope for the future;

(2) the ready availability of small arms from an international arms market, in which the major world powers and the states of the former Soviet camp are the major sellers; and

(3) the ability of power and wealth hungry warlords and political entreprencurs to utilise the first two factors to achieve their aims.

With the Kalashnikov or other semi-automatic rifles as status symbols and as tools for extortion, looting, rape and killing, unemployed young men ansd boys are easily attracted by warlords and rebel leaders into their armed bands. Whether recruitment is made in an inclusive manner or on the basis of ethnicity is a function of local history and the particular pattern of ethnic identity construction and mobilisation in each country. It has to do with politics. 
In the political sphere, the state operates mostly as the property of those who hold political power and their entourage, rather than as an impartial system of institutions which serve the general interest. This privatisation of the state, together with the resulting failure to fulfil the people's aspirations for democracy and economic development, has led to the erosion of its legitimacy and to a reduced capacity for good governance. The crisis of the state thus creates an environment in which violent conflicts are likely to thrive. Whereas the breakdown of state authority creates a power vacuum, which different political forces may use to advance their own agendas, the erosion of state legitimacy often drives authoritarian rulers to unleash a violent backlash against the forces advocating democratic change. When power holders themselves are defined primarily as regionally or ethnically based groups, belonging to the right group may be a badge of honour, while the exclusion of other groups becomes a major ground for fighting the system.

The very nature of the state as a regionally or an ethnically defined monopoly of power is thus a major factor in identity-based conflicts. Since the state is still the primary avenue of wealth accumulation and the principal employer of wage labour in most African countries, maintaining access to the state and to the resources it controls is a major goal for individuals and social groups. As John Markakis has pointed out in his study of conflict in the Horn of Africa, access to the state and state-controlled resources is the bone of contention in class and ethnic conflicts in Africa. ${ }^{11}$ With the state as a prize, the parties to a conflict engage in a dcadly zero-sum game, and resort to violence as the most effective means for winning and keeping the prize.

The use of violence, however, leads to the destruction of existing capacity and to the further erosion of state legitimacy among the losers, who are likely to be excluded from power and from state-controlled resources. Violent conflicts have unleashed untold suffering on millions of innocent men, women and children, and entailed heavy costs for the countries involved, as well as for their neighbours, who must cope with the problem of refugees. The destruction of the natural environment, of the physical infrastructure and of invaluable social services has reduced the capacity of the 
state and the economy to meet the most basic human needs. A major cause of conflict and poverty is also its inevitable result.

\section{Ethnic Conflict and the State in Africa}

What are the conditions under which different ethnic groups enter into conflict with each other, and how are these conflicts related to state politics? The best way to answer this question is to examine the major types of ethnic conflict on the continent today, together with their causes, substance and political consequences. Three types of ethnic identity conflict are examined below:

(1) inter-communal violence over economic and social space;

(2) rebellions by oppressed minorities; and

(3) ethnic cleansing and genocide.

\section{Inter-communal Violence}

Inter-communal violence refers to violent conflicts between different ethnic groups or between subdivisions of a group (lineages, clans, regions, etc.). It is a sign of the times that such violence is on the increase in Africa today. Seldom does a week pass without reports of fighting between rival communities over something, mainly land, but also over other resources. Once a violent conflict breaks out, even the most minor slights and humiliations towards a member of a given group from the side of its adversary can provoke renewed fighting, as the wronged group seeks to defend its honour. With each killing and destruction of property requiring revenge, the violent confrontation may go on long after the initial bone of contention has been forgotten. What is important for our purposes here is to identify what is at stake in such conflicts, their violent manifestations, and the state's role in these confrontations as the object of the conflict, fire fighter, instigator, or conciliator.

Much inter-communal violence takes place because of competition between two or more groups over economic and social space. With land for farming and grazing diminishing steadily, owing to many factors, conflicting claims over land or territory can lead to serious conflict in areas where community boundaries are neither 
clear nor accepted as legitimate. Territorial disputes are also prevalent in the mobilisation of ethnic cleavages to secure economic and political advantages, as in the case of the Somali clans and their warlords in Mogadishu and other strategic areas, and in that of the political leaders of Congo-Brazzaville and their ethnically based armed militias. Competition over other economic and social resources also brings groups into conflict. In Nigeria, for example, communities have gone to war over the location of a local government office, with all that this implies for state recognition of local authority structures. That poor communities should fight each other for an office like the chieftaincy, whose material benefits for the entire community are so limited, is an indication of how poverty can exacerbate conflict among human beings.

Inter-communal confrontations are generally accompanied by a high degree of violence. This involves killing the enemy, in addition to burning and destroying their crops, livestock and dwellings. As in other types of identity-based conflicts, such violence may result in the internal displacement of populations. ${ }^{12}$ The methods and the technology of war may be traditional, and much that is happening today in the Niger Delta may be reminiscent of scenes from Chinua Achebe's (1958) novel, Things Fall Apart, but what is at stake is access to the state and to the resources it controls. Whatever the original grievances that the Ijaw, Itsekiri and other ethnic communities had against each other, there is a genuine suspicion among Nigerian scholars that outside dominant interests, with a strategy of divide and rule, are instigating inter-communal fighting between groups who should really be banding together against the state and the transnational oil companies, in a common struggle for a clean environment, economic justice and social progress. ${ }^{13}$

State involvement in the prevention, management and resolution of inter-communal conflicts is generally a function of the strategic importance of the area affected to the wcalth extraction and revenue collection priorities of the central government. If the violence is taking place in an area rich in oil, other mincral resources, major cash crops, or tourist facilities, the response is usually swift and brutal. Elite units of the military may be sent to assist the police in maintaining law and order. When it occurs in areas of 
minor importance to the country's economy, benign neglect is likely to be the prevalent attitude in African capitals. ${ }^{14}$ With the exception of Somalia, where inter-communal violence has effectively destroyed the state as an institution of rule and social cohesion, this type of ethnic conflict does not pose a major threat to the state as an institution or to its territorial integrity. Locally specific, it does not endanger peace and security in the country as a whole.

\section{Rebellions by Oppressed Minorities}

A single ethnic group may engage in inter-communal violence as well as in acts of rebellion against political and social oppression by the dominant interests. This is the case with the ethnic communities of the Niger Delta vis-à-vis the Nigcrian state and the transnational oil giants, BP, Shell, Chevron, Mobil and the others. As one ljaw community leader told a reporter from the Associated Press earlier this year, "We, the owners of the Niger Delta have become its slaves... We are oppressed, so we don't mind fighting to the last woman or man alive'.15

Conflicts involving the rights of ethnic minorities are perhaps the greatest challenge to the state and to its nation-building strategy of national integration in contemporary Africa. They have to do with the self-assertion of oppressed minorities sceking to exercise their full citizenship and democratic rights. In asserting their dignity as peoples with inalienable rights, these minorities reject what they perceive as injustice or their treatment as sccond-class citizens.

Sociologically speaking, according to Georges Balandier, ${ }^{16} \mathrm{mi}$ nority status has little to do with numbers. A numerical majority may be reduced to the status of a sociological minority, in being economically dominated and/or politically and socially oppressed by the numerical minority that holds political power. This was the case under colonialism in the colonial-settler state of apartheid South Africa and in the Americo-Liberian system in Liberia. It is the case today under the conditions of ethnic polarisation in Rwanda and Burundi, where the Tutsi minority controls the state system.

Ethiopia, the only African state not to experience colonial rule, apart from the six-year occupation by Fascist Italy from 1935 to 
1941, also had a system in which one ethnic group imposed its political and cultural hegemony over all the others. Its recent history, from 1960 to 1991, offers us the best framework for understanding rebellions by oppressed minorities. Although it emerged in Tigray during the fourth century $\mathrm{AD}$, with the Christianisation of the ancient kingdom of Axum, the Ethiopian state became identified with the Amhara cultural tradition during the twentieth century. The imperial state had shifted from place to place before it settled at Shoa, in the Amhara hinterland, by the end of the nineteenth century. The post-war modernisation, undertaken by Emperor Haile Selassic, seems to have favoured the Amhara ruling classes and petty bourgeoisie. Although they formed only a quarter of the Ethiopian population, the Amhara were heavily represented in all state organs, including the armed forces, where 70 percent of all officers were Amhara in 1970. ${ }^{17}$ With the Ethiopian state identified with the Amhara language and culture, members of other ethnic groups 'found it much harder to reach middle or high ranks in the public service'. ${ }^{18}$

With the independence of most African countries in the 1960s, Ethiopians began to see just how economically and politically backward their country had remained under imperial rule. Three major ethnic groups, the Tigrayans, the Oromo and the Somali, began to voice their discontent with the system. Since Tigray had historically been part of the Ethiopian Empire, Tigrayan resistance to the central state was related to the contemporary issues of conomic neglect and discriminatory practices by the state. The 1972-73 famine in Wollo and Tigre provinces, which claimed over 100,000 lives, was clear testimony to the official indifference of Addis Ababa towards peripheral provinces. Despite its Marxist rhetoric, the military regime of Mengistu Haile Mariam did not change things for the better in the interior. The Tigrayan People's Liberation Front (TPLF), led by Meles Zenawi, cmerged as the leading organisation in the coalition of guerrilla movements known as the Ethiopian People's Revolutionary Democratic Front (EPRDF), which overthrew the Mengistu regime in 1991, with some support from the Eritrean People's Liberation Front (EPLF) of Isaias Afwerki. 
A good example of minority status in a multiethnic context is the case of the Oromo people, who are the most numerous ethnic group in Ethiopia. Imperial rule was imposed on them during the nincteenth century territorial expansion of Ethiopia southward. From the fact of conquest, their minority status was existentially marked by excessive payment of tribute to feudal lords, who took three quarters of the harvest, a 10 per cent land tax, and corvée labour. ${ }^{19}$ For the Oromo, the Ethiopian state was an alien and oppressive system, from which they wanted to detach themselves by exercising their right to self-determination. In 1975, one ycar after the military-dominated Revolution, they formed the Oromo Liberation Front (OLF). Although the OLF is still committed to self-determination, the people of Oromia seem willing to give the new system of ethnically autonomous regions under the Meles regime a try.

Like the Oromo, the Somali were incorporated into the Ethiopian state during the territorial expansion of the nineteenth century. In the case of the Somali clans of the Ogaden, the birthplace of modern Somali nationalism, with Mohamed Abdille Hassan the 'Mad Mullah' for the British imperialists - their incorporation into Ethiopia was part of the colonial partition of Africa. After having defeated the Italians at Adowa in 1896, Emperor Menelek II engaged in diplomatic manocuvres with the British, the French and the Italians in drawing up the political map of the Horn of Africa. Although the Ogaden and the Haud represent one of the five stars on the Somalian flag, the irredentist dream of Greater Somalia has been transformed into the nightmare of warlordism and endless divisions. ${ }^{20}$ Little is heard today of the Western Somalia Liberation Front (WSLF) and its project for over one million ethnic Somali to owe their allegiance to Mogadishu rather than Addis Ababa. With the chaos in Somalia, these people have a chance to see what the new federal system in a multiethnic and multicultural Ethiopia might allow them to do for the promotion of Somali culture.

The constitution of the Federal Democratic Republic of Ethiopia provides for decentralised government in ethnically homogenous or culturally coherent regions. While defenders of federalism point to the Ethiopian experience as a potential model for 
other countries, there is a lot of scepticism among Ethiopian intellectuals whether the Meles regime will really allow these regions to have the resources and the freedom to do what they want politically, economically and culturally. Some see the system as inimical to national unity, because of the tribalism and chauvinism that may be encouraged by preventing people from participating in the affairs of regions other than their own region of origin. Although the constitution recognises the right of self-determination, up to and including secession, no one expects secession by any region to be approved by the centre. Not only are the conditions for eligibility almost impossible to meet; the current war with Ethiopia's former province of Eritrea is likcly to silence any talk of secession for a very long time indeed.

Less complex than the situation in Ethiopia are the rebellions of oppressed minorities based on the north-south divide in countries such as Sudan, Chad, Niger and Mali. The north-south problem in Chad and Sudan revolves around the coexistence of two cultural zones: the zone of predominantly Islamic Arab culture in the north, and the zone of black African culture in which African religions, Christianity and Islam are to be found. ${ }^{21}$ In the cases of Mali and Niger, both sides of the cleavage are Muslim, the main difference being between the black African majority, whose elite control the state in the south, and the partially Arabised Tuaregs in the north. Violent conflicts in all four countries were part of the minorities' response to powerlessness, economic neglect, and oppression. Progress is being made in integrating the Tuaregs into the social fabric of Mali and Niger, while the long civil war in Chad has been superseded by party politics under the firm control of General Idris Deby. The south seems to have lost political control in N'Djamena to the benefit of the centre and the north.

The north-south cleavage in Chad and Sudan was primarily a function of the legacy of the colonial political economy. For the colonialists, only those regions deemed to be economically 'useful' were to have infrastructure development and supportive social services, such as education and health. In Chad, this meant the southern and central regions, with cotton and beef as export commodities, respectively. But the African elite came mostly from the south, 
since there was little schooling available for children of the pastoralists of the centre. In Sudan, it was the north, with its historical and economic links with Egypt, that was administered by the elite Sudan Political Service, while the south was run by military officers until the 1920s and by a special group of administrators thercafter. Everything was done to kecp anything Arab or Muslim-Arab language, names, dressing, traders, Islam-from the south. Having administered the two regions of the country as separate and unequal parts, the British and their Arab allies in Egypt and Sudan insisted on making independent Sudan a unitary political system.

With independence in 1956, Arabic became the national language and Islam the state religion. Given the economic backwardness of the south, Arab civil servants were generally the only ones qualified to occupy the higher ranks in the administration. For the region, this meant $\Lambda$ rab colonialism, which had to be resisted. Southern demands for federalism were rejected, and rebellions in the south led to the imposition of military rule on the region. This is the background to the emergence of the secessionist movement of the Anya-nya, who fought a bloody civil war with the Sudanese army between 1963 and 1972. The Addis Ababa agreement of 1972 officially ended the war and gave regional autonomy to the south, while several top Anya-nya leaders joined the government in Khartoum.

This agreement did not, however, contribute to improving the material conditions of the broad mass of the people, who remained receptive to the idea of continuing the struggle. By 1983, a new and more radical political organisation, the Sudanese People's Liberation Movement (SPLM), had assumed the leadership of the popular struggle, not for another secessionist drive, but for the liberation of Sudan as a whole. The SPLM benefited greatly from the errors of President Jaafar Numeiry, who had decided to split the south into smaller administrative units, so as to better control them, and to impose the Shari'a or Islamic code on all Sudanese, including non-Muslims. After 16 ycars of war, the SPLM is still committed to self-determination, but in any framework that Southern Sudanese may approve in a referendum. In other words, secession is 
no longer excluded from its programme. ${ }^{22}$ Financially and otherwise exhausted by the war, Khartoum and its National Islamic Front (NIF) leadership seem willing to consider the partition option. A major obstacle in this regard is Egypt. Already concerned by Ethiopia's control of the Blue Nile, Cairo does not wish to see the White Nile fall under the control of another non-Arab country.

Although an oppressed ethnic group may rise up to assert its right to self-determination, including the setting up of a separate nation-state, rebellions by oppressed minorities do not have the redrawing of the political map of Africa through secession as a major objective. They are mostly attempts at redressing genuine grievances by groups that have been denied their full rights as citizens. Rather than dismissing them as 'bandits' or 'hooligans', governments should seek to establish dialogue with these groups and should work with them to solve the underlying issues of the conflict. An even better approach is to enforce the principles of fairness and equal opportunity in public policy, and so prevent conflicts from arising in the first place.

\section{Ethnic Cleansing and Genocide}

The last major type of ethnic conflict situation is the one involving 'final solution' scenarios of ethnic cleansing and genocide. As the most extreme manifestations of identity-based conflicts, ethnic cleansing and genocide require the full weight of the state and its support for both state and non-state actors involved in carrying out the final solution. Ethnic cleansing is the forcible removal of people of a given ethnic group from a geographical area. All means, including the destruction of property, torture, rape and murder, are used to scare people into running away. The surviving victims then become refugees or internally displaced people. Genocide, on the other hand, is defined as 'acts committed with intent to destroy, in whole or in part, a national, ethnic, racial or religious group'. ${ }^{23}$ Both the act of genocide and incitement to genocide are crimes under international law.

The most recent and major case of ethnic cleansing in Africa occurred in Congo-Kinshasa between 1992 and 1994. The target populations were people of Rwandan origin in North Kivu and 
people from the two Kasai provinces living and working in the Katanga province. In both cases, the late President Mobutu Sese Seko and his cronies were using the ethnic card to divide the population and thus weaken the democracy movement. While the people affected in Kivu could seek refuge across the border in Rwanda, the approximately one million Kasaians expelled from Katanga had a long trek of approximately $1000 \mathrm{~km}$ (or 625 miles), during which thousands died of exhaustion, hunger and attacks by wild animals. Those who waited for trains were subjected to insanitary living conditions around railroad stations, overcrowded and slow moving trains that were often derailed because of old and faulty equipment, and attacks on and off the trains by the armed militia of the Katanga provincial governor, Gabriel Kyungu wa Kumwanza.

Today, the génocidaire Kyungu is the Democratic Republic of Congo (DRC) Ambassador to Kenya. That a person who had committed heinous crimes against humanity should work as a close collaborator of DRC President Laurent-Désiré Kabila is a testimony to Kabila's preference for people from his own region - both Kabila and Kyungu are Luba-Katanga - in political appointments and to his blatant indifference to moral values in governance. In 1992, the National Conference had voted overwhelmingly to put an end to the politics of impunity in the DRC, Then Zaire.

Genocide is a rational plan, but the choices that go into it are a function of events that are not entirely made by the génocidaires themselves. The economic, political and social aspects of the historical background need to be examined for a fuller understanding of genocide. ${ }^{24}$ In Rwanda in 1994, the state was clearly an instigator of the genocide, which was presented as the 'work' of all those who were or were supposed to be loyal to the state. As Philip Gourevitch points out, "the work of the killers was not regarded as a crime in Rwanda; it was effectively the law of the land, and every citizen was responsible for its administration'. ${ }^{25}$ That is to say that those targeted for death were not perceived as citizens; in fact, they were not even seen as human. Demonising and animalising the targets of ethnic cleansing and genocide allowed the perpetrators to feel justified in their cause and behaviour. 
The roots of genocide in Rwanda and Burundi lie deep, not in ancient enmities, which did not exist, but in the history of ethnic identity construction and mobilisation during the last half century under the colonial and postcolonial states. Originally, the categories 'Hutu' and 'Tutsi' were not ethnic. They referred to social ranks associated with occupation and proximity to the royal court. The colonial policy of divide and rule gave preference to the Tutsi in education and civil service employment until the mid-1950s. Since the Tutsi elite were heavily involved in the struggle for independence, the Belgian colonialists opted for the promotion of a Hutu counter-elite as a counterweight to the Tutsi. The Hutu took advantage of this promotion and succeeded in removing the Tutsi from their dominant position in Rwanda. Seeing what had happened in Rwanda, the Tutsi elite in Burundi did everything possible to keep power in their own hands, including a selective genocide against Hutu intellectuals, real as well as potential. Now that the Tutsi have succeeded in regaining power in Rwanda, the current situation there resembles the pre- 1959 political order, but one without the monarchy and Belgian colonial officials.

Ethnic cleansing and genocide do not pose a threat to territorial integrity, as they are carried out or supported by the state itself. The spillover effects of the 1994 genocide, however, included the violation of the DRC's territorial integrity, first by the Hutu power regime, which re-established itself on foreign soil with the entire Rwandan state treasury and armed forces; and then by the successor regime of Paul Kagame, which has now invaded the Congo on two separate occasions, in 1996 and in 1998.

\section{Threats to Territorial Integrity: Secessionist Movements and Cross-Border Invasions}

\section{The Problem of Boundaries}

The argument that much of the turmoil in Africa today is due to the artificial boundaries created by the imperialists, without regard to ethnic boundaries, is as simplistic as it is misleading. It is simplistic because it assumes that African precolonial boundaries were 
less artificial and that boundaries elsewhere are natural. According to Berman, "pre-colonial political and socio-cultural boundaries were marked by fuzziness and flexibility; and Africans existed within a reality of multiple, overlapping and alternative collective identities'. ${ }^{26}$ Moreover, most boundaries in the world are artificial, in that they are lines whose exact position is often subject to dispute between states. Even natural boundaries give rise to positional disputes, as when a river suddenly changes its course. ${ }^{27}$

The argument is misleading because it implics that if ethnic boundaries were respected, African countries would be more coherent ethnically and would not experience so much ethnic turmoil and cross-border violence. Looking at the ethnic map of Africa, one can see that however much one might try to avoid splitting a group among two or three different countries, whichever country the group found itself in would be multiethnic. Or do those who deplore artificial borders hope for a redrawing of the map to restore precolonial political entities? Should groups now divided among three separate countries, such as the Kongo, the Lozi or Barotse and the Lunda, be allowed to form ethnically homogenous nation-states? ${ }^{28}$

Africa is not alone in this predicament over the national question. The borders that separate countries cut across national or ethnic groups in some parts of Europe and Asia as well. Ethnic Germans, for example, are found in nearly all countries surrounding the Federal Republic of Germany-from Belgium, where they enjoy the same status as a self-governing community as their more numerous Flemish and Walloon compatriots, to Central Europe. Albanians, Armenians, Basques, Hungarians and Kurds are just few of the non-African groups straddling national borders, whose plight has been highlighted in the world news media during the $1990 \mathrm{~s}$. There is also the problem of large immigrant communities, whose full integration in the countries where they reside poses some difficulties. Outside Africa, the two major cases are those of ethnic Chinese in Southeast Asia and ethnic Russians in Eastern Europe and Central Asia.

Much of the cross-border violence throughout Africa has nothing to do with ethnic groups that straddle national boundaries. 
Since independence, only two instances of irredentism have caused sufficient turmoil to become matters of serious political concern for the states involved. I am referring to the Somali case, already noted above, and to that of the Ewe of the Volta region of Ghana, who were separated from their kith and kin in Togo in the wake of World War I. If ethnicity in itself is not a threat to territorial integrity, where do such threats come from in Africa today? The two major sources of threats to territorial integrity are secessionist movements and cross-border invasions and annexations of territory.

\section{Secessionist Movements}

During the 1960s, two major wars were fought on African soil over the territorial integrity of the Congo and Nigeria. The first opposed a United Nations peacekeeping force against an army of white mercenaries and African troops defending the Katanga secession. Led by Moïse Tshombe, the secession of the Katanga province from the Congo had nothing to do with ethnicity. Tshombe's political party, appropriately known as a coalition of Katanga's ethnic associations (Confédération des associations tribales du Katanga, or Conakat for short), was a multiethnic organisation. The major rationale for the secession, according to its African leaders, was that the wealth of the Katanga province should serve mainly the interests of 'authentic Katangans' or those native to the province.

In reality, these Africans were basically instruments of the combined interests of the white settlers and the colonial establishment in Belgium, France and Great Britain, who wanted to maintain the mineral-rich province within the Southern African economic complex. It was only after Patrice Lumumba was assassinated, thus removing the major obstacle to the Western powers' ability to control the central state in Kinshasa, that the dominant metropolitan interests abandoned Tshombe and the settlers. Once U.S. President John F. Kennedy gave the green light, the once hesitant UN force wasted no time in defeating the secessionist forces and restoring Congo's unity. ${ }^{29}$

Unlike Katanga, the secession of Biafra, as the Eastern Region of Nigeria called itself, in its attempt to break away from the Fed- 
cral Republic in 1967, was tied to ethnicity. It was the result of ethnic nationalism in a context of interethnic conflict in which the Igbo of eastern Nigeria felt that their economic, political and even physical security was threatened. The events leading to the secession are widely known. Suffice it to say that it all began with the coup d'état of January 1966 by a group of Igbo majors, whose idealistic aim was to purify Nigeria by ending corruption and mismanagement. The fact that not a single Igbo politician was found among the leaders killed convinced the rest of Nigeria that the coup was simply a prelude to the establishment of Igbo domination. Coincidentally, the senior army officer who inherited the reigns of power was himself an Igbo. The politically inept regime of Major General Johnson Aguiyi-Ironsi only helped to worsen matters. His decision to set up a unitary system of government was seen by many in the rest of the country as the final move by his entourage of mostly Igbo aides to cement Igbo domination of the country through control of the civil service and other public sector jobs, as well as through access to government contracts, services, and development projects.

Anti-Igbo pogroms in the north and the assassination of Igbo officers during the counter-coup of July 1966 created a catastrophic situation, in which the Igbo became justifiably worried about their survival as a people. The call went forth to Igbo living in other parts of Nigeria to return to their homeland. Here, the Igbo bourgeoisie and petty bourgeoisie saw their chances of making up for their political and economic losses elsewhere, inasmuch as Biafra was defined as coterminous with the entire Eastern Region, including the oil-rich Niger Delta inhabited by non-Igbo ethnic minorities. With the intensification of ethnic nationalism at a time when the federal government was weak, the mass of the Igbo pcople overwhelmingly embraced the secessionist option.

France supported the secession in an active way, primarily through its African surrogates in Gabon and Côte d'Tvoire, as it would have served its strategic interests to break up the only country likely to challenge its hegemony in West Africa. The Nixon White House voiced sympathy for it, as did some religious and humanitarian organisations. On the whole, however, Africa and the international 
community remained supportive of Nigerian unity and territorial integrity. The Nigerian civil war of 1967-70 ended with the victory of the federal government. Most Nigerians and foreign observers agree that by avoiding recriminations and war tribunals in favour of genuine reconciliation and forgiveness, the military regime of General Yakubu Gowon created the conditions under which the war experience could help consolidate Nigerian nationhood and unity.

Other than the war in Southern Sudan, there are no major secessionist movements on the African continent today. The autonomist movement in the Casamance region of Senegal and the current challenges to national unity in the Comoro Islands have more to do with economic grievances than with systematic political and social oppression, as in the Sudan case, or momentary threats to a group's physical security, as in the cases of Biafra and, earlicr, the 1960-62 South Kasai secession in the Congo. ${ }^{30}$ With the exception of Biafra and South Kasai, which were, respectively, mainly Igbo and Luba-Kasai affairs, and of the specific case of Somali irrendentism, African secessionist movements have been multiethnic.

The experiences of Nigeria and the Congo, where groups that had fought each other bitterly were soon after able to work together as fellow citizens, show that the ethnic antagonisms that had given rise to the secessionist option are not irreconcilable. Much of the turmoil in such conflicts has to do with political leaders seeking economic and political advantages, and with the inexperience of the states involved in developing ways of institutionalising interethnic conflict through peaceful means. As long as they remain class societies, marked by inequality and scarcity, the countries of Africa, like multiethnic societies all over the world, are condemned to live with interethnic competition in the social, economic and political arenas.

\section{Cross-Border Invasions and Annexations of Territory}

The greatest threat to regional stability and territorial integrity in Africa today arises from the arrogant and shameless attempt by 
some countries, with strong external backing, to redraw the map of Africa unilaterally, by illegally occupying a neighbouring state on the basis of historical or sccurity claims. There are three major examples of this type of behaviour, none of which is directly related to ethnic identity politics in the country being victimised. The first case is that of the invasion and illegal occupation of Western Sahara by Morocco. The second is Ethiopia's annexation of Eritrea in 1962, which ended in 1991 after 30 years of war, while the third case is the current aggression against the Congo by Rwanda and Uganda.

Morocco claims that Western Sahara is an integral part of Greater Morocco, a historical kingdom that fell victim to French and Spanish imperialism in the ninetenth century. In 1960, Morocco tried its best to prevent the independence of Mauritania, which it also claimed as part of the historic empire. In 1962, Morocco went to war with Algeria over the iron ore rich regions of Tindouf and Gara-Djebilet, which it also claims as Moroccan territory. Although the International Court of Justice ruled in 1975 against Morocco's claim to the then Spanish colony of Western Sahara, the Moroccan king ordered a "green march" of thousands of volunteers, who invaded and settled in the territory. Since 1976, when the Spanish left, Morocco has militarily occupied the territory, waged an aggressive war against the Saharawi people and their liberation movement, the Polisario Front, and done its best to frustrate all attempts by the UN and the OAU to resolve the dispute through a free and fair referendum among the genuine inhabitants of Western Sahara.

That a country that joined the United States and others in fighting Saddam Hussein's invasion of Koweit could get away with its own invasion and occupation of Western Sahara is clear testimony to the double standard in the enforcement of international law, particularly for client countries like Morocco with powerful patrons such as France and the United States. Morocco and the U.S. have a friendship treaty dating back to 1787. According to Stephen Zunes, it is the longest unbroken peace agreement that Washington has maintained with any country in the world. ${ }^{31}$ Their special relationship since Moroccan sovereignty was re-established in 1956 has to do with U.S. strategic interests in the north-western corner 
of the African continent on the Atlantic and Mediterranean coasts as well as in the Middle East. Morocco and the U.S. have also cooperated militarily in establishing and supporting pro-Western African regimes like the Mobutu dictatorship in the Congo and in destabilising radical regimes. In 1960, General Kettani, the Moroccan deputy commander of the UN Force in the Congo, helped Mobutu to mount his coup d'état against Prime Minister Lumumba. Because of its close ties to Washington, Morocco has received more U.S. military and economic assistance than any other African or Arab country, with the exception of Egypt. ${ }^{32}$

Haile Selassie's Ethiopia also enjoyed a close relationship with the United States, and this allowed the Emperor forcibly to annex Eritrea in 1962. An Italian colony, whose borders were determined in an 1889 treaty with Emperor Menelek, Eritrea became a British protectorate in 1941, following the defeat of Italian forces in the Horn of Africa. For Eritreans, the periods of Italian and British rule helped to forge a common and distinct identity, which later manifested itself in their demands for self-determination and independence after World War II. For evident strategic considerations, which included the desire to gain a foothold in north-east Africa and the Red Sea region, the United States manoeuvred at the United Nations to satisfy the wishes of Haile Selassie. Thus, when the vote was taken on the $\mathrm{UN}$ resolution concerning the future of Eritrea in 1950, the U.S. voted for federation with Ethiopia, while the Soviet Union passionately defended the right of the people of Eritrea to self-determination. As stated by John Foster Dulles, who later served as U.S. Secretary of State under the Eisenhower Administration, the rationale for the U.S. position is as follows:

From the point of view of justice, the opinions of the Exitrean pcople must receive consideration. Neverthcless, the strategic interests of the United States in the Red Sca basin and considerations of security and world peace makes it necessary that the country has to be linked with our ally Ethiopia. ${ }^{33}$

When Ethiopia changed alliances after the 1974 Revolution, the Soviet Union became its major patron and the chief provider of military assistance in the Derg's repeated offensives to crush the Eritrean liberation strugglc. The people of Eritrea liberated them- 
selves in 1991, but had to await a UN-supervised referendum in 1993 to become a sovereign state. U.S. allies, Ethiopia and Eritrea, are currently involved in a vicious war over a border dispute concerning a useless piece of sandy territory around Badme.

The last major threat to territorial integrity concerns the invasion of the Congo by Rwanda and Uganda, two other U.S. allies that, like Ethiopia and Eritrea, are governed by what some American policymakers and academics consider a 'new breed' of African leaders. Elsewhere, I have shown that the security rationale advanced by Kampala and Kigali for their aggression in the Congo is a smokescreen for their real ambitions, which are guided by economic and strategic interests. ${ }^{34}$ Although Rwandan leaders have talked about historical claims to territory in North and South Kivu and the need for a second Berlin Congress to re-examine boundaries, they know that Africa as a whole will remain hostile to such designs.

For this reason, Rwandan and Ugandan authorities want to create a buffer security zone, similar to Israel's self-proclaimed security zone in southern Lebanon. While useful in diminishing the number of raids by rebels from their countries operating from the Congo, such a territory would mainly serve as a zone of settlement and cconomic exploitation by resource poor countries, one of which is also overpopulated. Such a zone would also allow transnational mining firms, who have lost patience with the breakdown of state authority in the Congo since 1990, to extract the strategic minerals they need for the twenty-first century from the enormous wealth of north-eastern Congo. These concerns, rather than a preoccupation with the plight of Congolese Tutsi like the Banyamulenge, are the real causes of the current war in the Congo, in which countries aligned with the Kabila government, such as Angola, Chad, Namibia and Zimbabwe are also attempting to advance their own economic and strategic interests. 


\section{Conclusion}

Africans have for the most part concluded that nothing can be gained from revising the borders inherited from the colonial period. Any attempt to do so would be like opening the Pandora's box. Trying to redraw the map to satisfy everyone could only succeed in creating a madhouse, while satisfying no one. This is why the 1964 OAU resolution on the inviolability of colonial frontiers makes absolute sense. Rather than wasting time and energy in deploring them, every effort should be made to render them meaningless by promoting and increasing the free movement of people and goods, which is a sine qua non of economic integration and development. It is scandalous that visas should be required for Africans to travel within their own continent, when certain categories of nonAfricans can enter many of our countries without visas.

The situational character of identity-based conflicts calls for greater attention to the economic and political causes of identity construction and mobilisation, as well as to the crises that engender and exacerbate conflicts. For these conflicts are ultimately related to the nature and role of the state in postcolonial Africa, including the state's role in the economy and the manner in which state power is exercised. In other words, their root causes are to be found in the economic sphere and in governance. The external cnvironment is also a major factor to take cognisance of, as the interests of major powers lead them to enter into alliances with leaders who may use military assistance and political support from their patrons for aggressive purposes against their neighbours.

For the African state, the major lesson of ethnic identity politics and conflicts is to avoid exclusionary policies and practices. Given the relatively low level of economic and social development in the continent, finding innovative methods of power sharing and ensuring access to the state and state-controlled resources for all rclevant social forces are categorical imperatives for peace and security in the foreseeable future. Patriotic and pan-African forces should do their best to promote national reconciliation and help to prevent or resolve violent conflicts. Containing identity-based conflicts within the arena of non-violent political competition is a 
necessary condition for building multicthnic political coalitions and strengthening the institutional foundations of economic recovery and good governance.

\section{Notes}

' Ian Fisher and Norimitsu Onishi, 1999, 'Congo's Struggle May Unleash Broad Strife to Redraw Africa', The New York Times, January 12.

2 On the socio-psychological dimension of identity-based conflicts, see Okwudiba Nnoli, 1989, Ethnic Politics in Africa, Apapa, Lagos: AAl'S Books, pp. $17-20$.

${ }^{3}$ Clifford Geert\%, 1963, "The Integrative Revolution: Primordial Sentiments and Civil Politics in the New States", in Clifford Geerty (ed.) Old Societics and Now States, New York: Free Press.

${ }^{4}$ David Apter, 1963, Ghana in Transition, New York: Atheneum, pp. 80-81; Apter, 1961, 1967, The Political Kingdom in Uganda, l'rinceton: Princeton University Press, pp. 18-20; Apter, 1965, The Politics of Modernization, Chicago: University of Chicago Press, p. 197; and Aristide R. Zolberg, 1968, 'The Structure of Political Conflict in the New States of Tropical Africa', American Political Science Review, Vol. 62, No. 1, March, pp. 70-87, esp. pp. 73-74.

'Goran Hyden, 1980, Beyond Ujamaa in Tanzania: Underdevelopment and an Uncaptured Peasantry, Berkeley: University of California Press; Hyden, 1983, No Shortcuts to Progress: African Development Management in Perspective, Berkeley: University of California Press.

6 This was a major theme in the literature of modernisation, a series that included titles like Daniel Lerncr's (1958) The Passing of Traditional Society: Modernizing the Middle East, Glencoe, IL: Free Press.

'Bruce J. Bcrman, 1998, Ethnicity, Patronage and the $\Lambda$ frican Statc: The Politics of Uncivil Nationalism', African Affairs, Vol. 97, No. 388 July, pp. 305-341, argues that modern African ethnicity is a social construction of the colonial period as a response to capitalist modernity. 
"See Nzongola-Ntalaja, 1985, "The National Question and the Crisis of Instability in Africa', Alternatives, Vol. 10, No. 4, Special UN Commemorative Issue, p. 548 .

${ }^{9}$ On the political transitions in Africa, see Eghosa E. Osaghae, 1995, "The Study of Political Transitions in Africa', Review of African Political Economy, Vol. 22, No. 64, June pp. 183-197, and Georges Nzongola-Ntalaja, 1997 and 1998, 'The State and Democracy in Africa', in Georges NrongolaNtalaja and Margaret C. Lee (cds.), The State and Democracy in Africa, Harare: AAPS Books and Trenton, NJ: Africa World Press, chap. 1.

${ }^{10}$ See Thandika Mkandawire, 1991, 'Crisis and Adjustment in Sub-Saharan Africa', in Dharam Ghai (cd.) The IMF and the South: The Social Impact of Crisis and Adjustment, London: Zed Books, pp. 81 -82.

"John Markakis, 1987, National and Class Conflict in the Horn of Africa, Cambridge: Cambridge University Press. See also Markakis, 199!, "The Bone of Contention in the Itorn of Africa', In Georges Nzongola-Ntalaja (ed.) Conflict in the I Iorn of Africa (Atlanta: African Studies Association Press, pp. 19-25.

${ }^{12}$ See John O. Oucho, 1997, "The Ethnic Factor in Internal Displacement of Populations in Sub-Saharan Africa', African Journal of Political Science, Vol. 2, No. 2 December, pp. 104-117.

${ }^{13}$ Ficld Rescarch Notes from Lagos and Abuja, Nigeria, 26-30 March 1999. ${ }^{14}$ This seems to be the case with the Ghanaian government, which has remained "very passive and indifferent" in the Dagomba-Kokomba land and chicftaincy conflict in the north, according to Joe Baidoc-Ansah, Executive Director of the Ghana Committee on Human and People's Rights. Interview in Accra, 31 March 1999.

is Glenn McKenzie, 1999, 'Nigerian Oil Dispute Threatens Vote', The Associated Press, February 19.

${ }^{16}$ Georges Balandier, 1963, Sociologie actuelle de l'Afrique noire, Second Edition (revised and enlarged), Paris: Presses Universitaires de France, pp. 3-38.

17 René Lefort, 1983, Ethiopia: An Heretical Revolution?, London: Zed Press, note 62, p. 18 .

${ }^{18}$ Ibid., p. 36.

19 See Bereket Habte Selassie, 1980, Conflict and Intervention in the Florn of Africa, New York: Monthly Review Press, for details on the system of exploitation in the south.

20 The five stars represent the five territories in which Somaliland was partitioned: British Somaliland (now the self-proclaimed Somaliland Republic), Italian Somaliland, the Ogaden and the Haud (in Ethiopia), French Somaliland (now the Republic of Djibouti) and the Northeastern Frontier District (NDF) of Kenya. In 1960, the former British and the former Italian colonies merged to form the Somali Democratic Republic, with its capital at Mogadishu. 
21 Gérard Galtier, 1984, 'Culture arabe et culture africainc: comment reconstruirre l'Etat tchadien', Le Monde diplomatique, November, pp. 1819.

${ }_{22}^{2}$ Personal communication from Lual Deng, 21 March 1999.

${ }^{23}$ Convention on the Prevention and Punishment of the Crime of Genocide, UN General Assembly Resolution 260A (III) of December 9, 1948.

${ }^{24}$ David Newbury, 1998, 'Understanding Genocide', African Studies Review, Vol. 41, No. 1, April, pp. 73-97.

${ }_{25}$ Philip Gourevitch, 1998, We wish to inform you that tomorrow we will be killed with our families: Stories from Rwanda, New York: Farrar Strauss and Giroux, p. 123.

${ }^{26}$ Berman, 'Ethnicity, Patronage and the African State', p. 310.

${ }^{27}$ Victor P'rescott, 'Boundary Disputes', 1993, The Oxford Companion to Politics of the World, New York: Oxford University Press, pp. 84-85.

${ }^{28}$ On the case of the Barotse of Zambia, Namibia and Botswana, see Al Venter, 'Barotses 'Threaten Secession', New African, March 1999, p. 19. The Kongo are found in Angola and the two Congos, while the Lunda are in Congo-Kinshasa, Zambia and Angola.

${ }^{29}$ For more information on the U.S. role in the Congo crisis, see Stephen R. Weissman, 1974, American Policy in the Congo, 1960-1964 (Ithaca: Cornell University Press; and Nzongola-Ntalaja, 1985, 'United States Policy toward the Congo', in Gerald Bender, James S. Coleman and Richard L. Sklar (eds.), African Crisis Areas and United States Foreign Policy, Berkelcy and Los Angeles: University of California Press.

30 The story of South Kasai has a lot of parallels with Biafra but it is not as well known. For a brief comparative analysis, see Nzongola-Ntalaja, "The National Question and the Crisis of Instability in Africa', pp. 546-551. ${ }^{31}$ Stephen Zunes, 'Foreign Policy in Focus: Morocco and Western Sahara', Foreign Policy in Focus, Vol. 3 , No. 42.

32 Ibid.

33 John Foster Dulles, cited in Linda Heiden, 1976, "The Eritrean Conflict', Africa Today, January-February, p. 46.

34 See Georges Nzongola-Ntalaja, 1998, 'The Crisis in the Great Lakes Region', Banquet Address to the African Renaissance Conference, Johannesburg, South Africa, September 28. 
